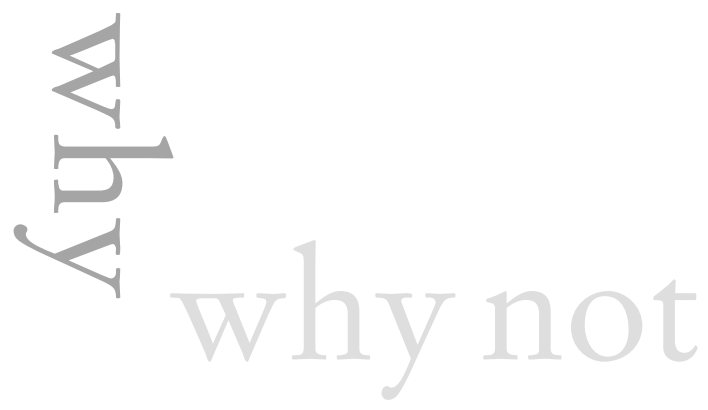





\section{martha ronk}

UNIVERSITY OF CALIFORNIA PRESS

Berkeley Los Angeles London 
University of California Press

Berkeley and Los Angeles, California

University of California Press, Ltd.

London, England

For acknowledgments, please see page 85 .

(C) 2003 by the Regents of the University of California

Library of Congress Cataloging-in-Publication Data

Ronk, Martha Clare.

Why/why not / Martha Ronk.

p. cm.-(New California Poetry ; 8)

ISBN O-520-23623-8 (alk. paper)-

ISBN O-520-23811-7 (pbk. : alk. paper)

I. Title. II. Series.

Ps3568.0574, w48 2003

$811^{\prime} \cdot 54-\mathrm{dc} 21$ 2002035356

CIP

Manufactured in Canada

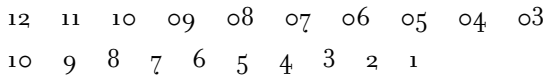

The paper used in this publication meets the minimum requirements of American National Standard for Information Sciences-Permanence of Paper for Printed Library Materials, ANSI-Z39.48-1984. () 
for Dale 
This page intentionally left blank 